\title{
PROTOTYPE SISTEM LAMPU PENERANGAN JALAN OTOMATIS MENGGUNAKAN SENSOR CAHAYA BERBASIS ARDUINO UNO
}

\author{
Muhammad Nurkhalis Agriawan ${ }^{1, a}$, Sania $^{2, b}$, Citra Ramita ${ }^{3, c}$, Nur Wahyuni ${ }^{4, d}$, Maisarah ${ }^{5, e}$ \\ $1,2,3,4,5$ Universitas Sulawesi Barat \\ Email: ${ }^{a}$ muhammadnurkhalisagriawan@gmail.com, ${ }^{b}$ saniania043@gmail.com, ${ }^{c}$ citrarasmita@gmail.com, \\ dwahyuninur556@gmail.com, elalamaisarah4@gmail.com
}

\begin{abstract}
Abstrak
Telah dilakukan pembuatan prototype sistem lampu penerangan jalan otomatis menggunakan sensor arduino. Proyek ini bertujuan untuk mengembangkan kontrol penerangan jalan umum yang dapat bekerja secara otomatis dan dapat menghemat pemakaian listrik. Dalam proyek akhir ini sensor yang digunakan adalah sensor LDR (Light Dependent Resistor) yang digunakan sebagai pendeteksi adanya cahaya pada tempat tersebut. Sensor LDR akan mengatur cahaya dari lampu sesuai dengan cahaya yang diterima oleh sensor LDR. Untuk mengatur cahaya dari lampu menggunakan rangkaian yang dikendalikan oleh Arduino Uno. Pada kegiatan yang telah dilakukan diperoleh lampu penerangan yang dapat bekerja secara otomatis, pada saat keadaan sekitar dalam keadan gelap (malam) maka lampu penerangan menyala, dan sebaliknya ketika keadaan sekitar terang (siang) maka lampu akan mati secara otomatis. Hal ini berarti sensor cahaya bekerja dengan baik.
\end{abstract}

Kata kunci : Arduino, Prototype, Sensor LDR

\section{PROTOTYPE OF AUTOMATIC STREET LIGHTING SYSTEM USING LIGHT SENSOR BASED ON ARDUINO UNO}

\author{
Abstract
}

A prototype of an automatic street lighting system has been made using an Arduino sensor. This project aims to develop a public street lighting control that can work automatically and can save electricity consumption. In this final project, the sensor used is an LDR (Light Dependent Resistor) sensor which is used to detect the presence of light in the place. The LDR sensor will adjust the light from the lamp according to the light received by the LDR sensor. To adjust the light from the lamp using a circuit controlled by Arduino Uno. In the activities that have been carried out, there are lighting lamps that can work automatically, when the situation is suddenly dark (night) then the lighting is on, and vice versa when the surroundings are bright (day) the lights will turn off automatically. This means the light sensor is working properly.

Keywords: Arduino, Prototype, LDR Sensor

\section{PENDAHULUAN}

Perkembangan ilmu pengetahuan dan teknologi dewasa ini semakin banyak memberikan kemudahan dalam kehidupan sehari-hari [1]. Teknologi yang dapat membantu manusia adalah alat yang dapat bekerja secara otomatis. Dimana segala hal yang banyak diterapkan ilmu pengetahuan dan teknologi dengan mesin ataupun elektronika, sehingga pekerjaan manusia dapat dikerjakan dengan mudah tanpa harus membuang tenaga dan mengefisienkan waktu.

Disamping itu dalam kehidupan seharihari, manusia cenderung menyukai hal-hal yang bersifat otomatis. Intensitas cahaya yang berasal dari lampu apabila diarahkan ke sebuah sensor dapat dimanfaatkan dalam sistem otomasi penyalaan lampu. Untuk itu dalam mengatasi masalah-masalah tersebut diperlukan alat yang bisa mengontrol sistem otomasi penyalaan lampu [2].

Dengan adanya lampu penerangan jalan tentu akan sangat memudahkan para pengguna jalan terutama di waktu malam hari. Akan tetapi kontrol penerangan lampu jalan yang dibuat masih menggunakan on off dengan timer sehingga lampu akan mati pada siang hari dan nyala pada malam hari, keadaan ini

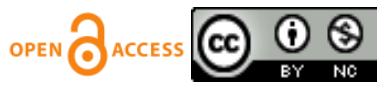


tentunya masih membutuhkan pemakaian listrik yang cukup besar.

Prototype adalah tahap setelah analisis siklus pengembangan sistem yang merupakan pendefinisian dari kebutuhan-kebutuhan fungsional, serta menggambarkan bagaimana suatu sistem dibentuk yang dapat berupa penggambaran, perencanaan dan pembuatan sketsa atau pengaturan dari beberapa elemen yang terpisah ke dalam satu kesatuan yang utuh dan berfungsi, termasuk menyangkut mengkonfigurasikan dari komponenkomponen perangkat keras dan perangkat lunak dari suatu sistem [3].

Arduino adalah pengendali mikro yang dapat deprogram dan dibuat dalam board mikrokontroler yang siap pakai dan di dalamnya terdapat komponen utama yaitu sebuah chip mikrokontroler jenis AVR. Arduino sudah diakui keunggulan dan kemudahanya dalam pemrograman serta harganya juga relatif murah. Selain itu software dan hardware-nya bersifat opensource di mana kita bisa berbagi desain/prototype kepada siapa saja dan juga bisa membuatnya sendiri [4].

Penelitian yang memanfaatkan mikrokontroler Arduino Uno sebagai sebuah sistem akuisisi data telah banyak dilakukan oleh peneliti beberapa tahun terakhir, seperti penelitian dengan menggunakan Arduino uno sebagai pengolah data analog menjadi data digital [5], sejalan dengan penelitian tersebut yang mengembangkan Sound Level Meter berbasis Arduino Uno sebagai pengukur tingkat kebisingan [6]. Penelitian mengenai pemanfaatan mikrokontroler Arduino uno sebagai alat untuk menguji kualitas air minum [7].

LDR adalah suatu resistor yang nilai resistansinya tergantung pada cahaya, jika mendapat cahaya terang nilai resistansinya kecil sekitar ratusan sampai dengan kilo ohm dan jika kondisi gelap nilai resistansi akan besar bisa mencapai puluhan ratusan $\mathrm{KOhm}$ bahkan bisa mencapai $\mathrm{M}$ Ohm, umumnya LDR digunakan sebagai sensor cahaya [8].

Penelitian tentang saklar otomatis berbasis Light Dependent Resistor (LDR) pada mikrokontroler Arduino Uno, tujuan dari penelitiannya tersebut yaitu untuk membuat saklar otomatis dengan menggunakan relay yang mendapatkan perintah apabila LDR dikenai cahaya, jadi lampu jalan akan mati secara otomatis apabila dikenai cahaya, sehingga dapat menghemat penggunaan listrik apabila lupa mematikannya [9]. Berdasarkan kondisi tersebut, maka dibutuhkan suatu sistem yang dapat menghemat penggunaan listrik untuk penerangan jalan dan juga dapat bekerja secara otomatis. Dalam hal ini dirancang suatu kontrol lampu jalan berdasarkan intensitas cahaya matahari yang dapat menghemat penggunaan listrik dan tentunya tidak mengurangi keselamatan pengguna jalan.

Penelitian sebelumnya yang terkait dengan lampu penerangan jalan otomatis diantaranya yaitu penelitian yang berjudul "Rancangan Instalasi Lampu Penerangan Jalan Umum Dengan Sistem Kontaktor Dan Timer" Pada penelitian ini menggunakan kontaktor magnet atau saklar magnet adalah saklar yang bekerja berdasarkan kemagnetan dan timer adalah saklar otomatis dengan prinsip kerja waktu tertentu dan dapat ditentukan sesuai yang kita tentukan kapan lampu akan menyala dan kapan lampu akan padam [10].

Peneliti lain yang relevan dengan penelitian dengan judul "Perancangan Prototipe Sistem Penerangan Otomatis Ruangan Berjendela Berdasarkan Intensitas Cahaya" Penelitian tersebut membahas tentang intensitas cahaya yang masuk ke dalam ruangan ketika terdapat manusia menggunakan sensor passive infrared dan sensor cahaya [11].

\section{METODE}

\section{Jenis Penelitian}

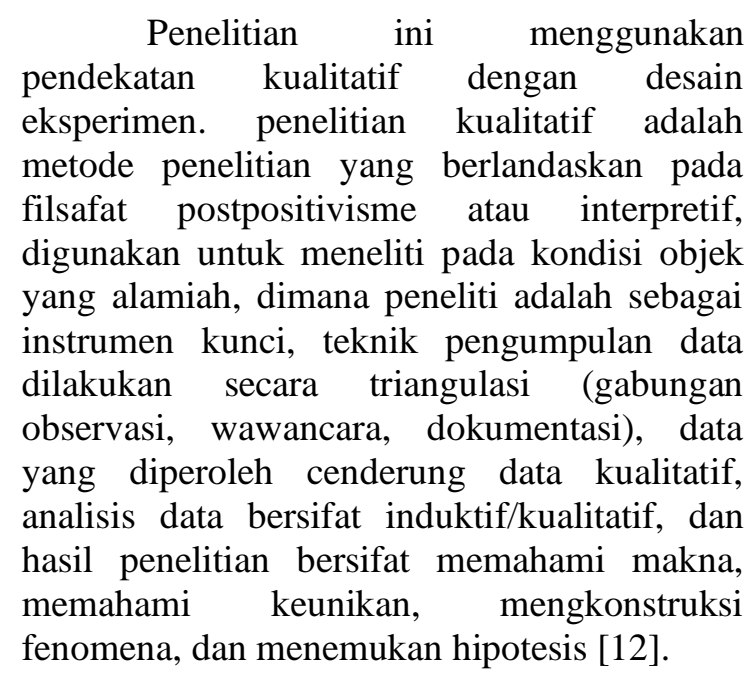




\section{Waktu dan Tempat Penelitian}

Waktu pelaksanaan kegiatan dimulai pada bulan november 2020 sampai pada bulan januari 2021

\section{Target/Subjek Penelitian}

Proyek akhir ini diharapkan akan memberi manfaat bagi masyarakat yang sangat membutuhkan penerangan lampu jalan terutama pada saat melakukan aktifitas diluar pada malam hari. Karena aktifitas masyarakat yang cukup padat pada malam hari dengan adanya lampu penerangan jalan tidak akan mengurangi keselamatan bagi para pengguna jalan.

\section{Prosedur}

Dalam penelitian ini, prosedur kegiatan yang akan dilakukan yaitu:

\section{Tahap persiapan}

Pada tahap ini dilakukan persiapan alat dan bahan yang akan digunakan. Pada kegiatan ini ada dua jenis alat yang disediakan yaitu hardware yang meliputi arduino UNO, kabel USB, kabel jumper 6 buah, breadboard, Lampu LED, Sensor cahaya LDR, Resistor 2 buah dengan hambatan $10 \mathrm{k} \Omega$ dan $220 \Omega$. Kemudian yang software yaitu arduino IDE merupakan aplikasi arduino yang digunakan untuk membuat perintah.

\section{Tahap pengambilan data}

Pada tahap ini dilakukan pengambilan data. Data diperoleh dengan cara mengatur keadaan penyinaran disekitar, yang meliputi keadaan sekitar cahaya terang, sedang dan redup.

\section{HASIL DAN DISKUSI}

Sebelum melakukan pengambilan data di lapangan terlebih dahulu dibuat Rangkaian sistem lampu penerangan jalan menggunakan sensor cahaya (LDR) dan LED berbasis Arduino Uno. Gambar rangkaian prototypenya terlihat pada gambar berikut:

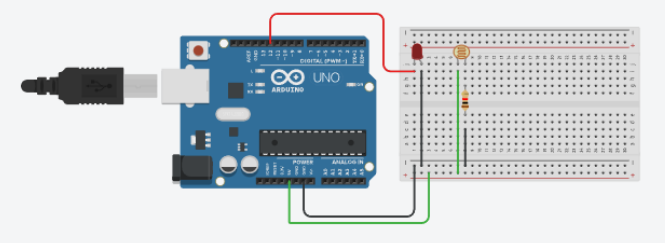

Gambar 1. Prototype Rangkaian Sistem lampu penerangan jalan

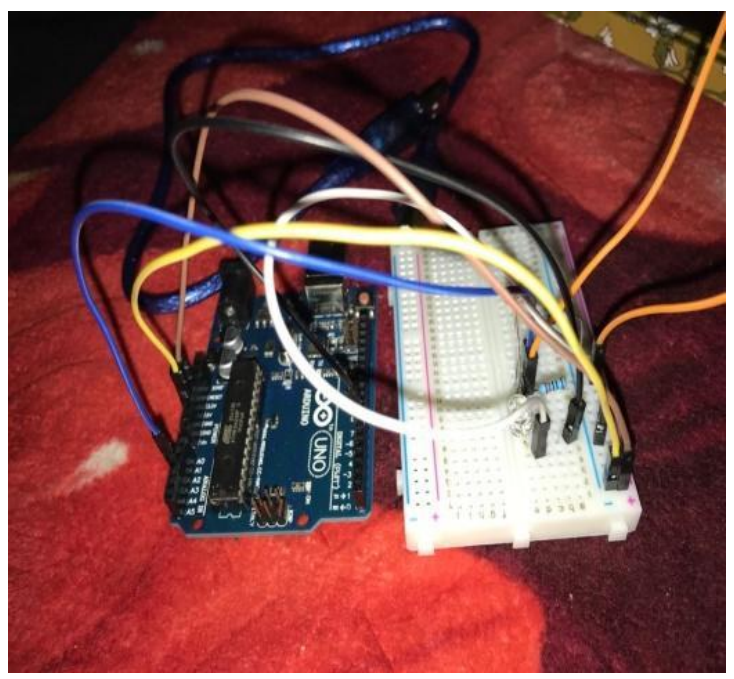

Gambar 2. Rangkaian alat

Setelah pembuatan rangkaian telah berhasil maka tahap selanjutnya adalah melakukan uji coba alat, Hasil data yang diperoleh pada kegiatan ini dapat dilihat pada tabel 1 berikut.

Tabel 1. Hasil pengamatan

\begin{tabular}{ccc}
\hline No & Intensitas cahaya & Kondisi lampu \\
\hline 1 & Redup & Menyala \\
2 & Sedang & Kedip-kedip \\
3 & Terang & Mati \\
\hline
\end{tabular}

Pengambilan

data

lapangan diperlihatkan pada tabel 1 . Hasil penelitian terlihat bahwa Ketika sensor LDR menerima cahaya redup maka LED akan menyala, dan Ketika sensor LDR menerima cahaya terang, maka LED akan mati.

\section{SIMPULAN}

Berdasarkan kegiatan yang telah dilakukan maka dapat disimpulkan bahwa pembuatan prototype sistem lampu penerangan jalan 
otomatis dengan menggunakan sensor arduino telah berhasil dilakukan, sehingga sistem ini dapat diterapkan pada lampu penerangan jalan umum.

\section{DAFTAR PUSTAKA}

[1] Sari, D. R. U,. Wahyuni, S,. Bachtiar. R. W,. 2018. PENGEMBANGAN INSTRUMEN TES MULTIPLE CHOICE HIGH ORDER THINKING PADA PEMBELAJARAN FISIKA BERBASIS E-LEARNING DI SMA. Jurnal Pembelajaran Fisika, 7(1). 100-107.

[2] Ramadhani, S., Alferinanda, Y., Asnil. Rancang Bangun Penerangan Jalan Raya Berbasis Arduino Uno. MSI Transaction on Education. 01(3). 103-114.

[3] Muzawi, R. dkk. (2018). Prototype Pengontrolan Titik Fokus Panel Surya Terhadap Energi Matahari Secara Otomatis Pada Stmik-Amik Riau. JURNAL INOVTEK POLBENG, Vol.8, No.1, ISSN 2088-6225, E-ISSN 2580-2798.

[4] Syahwil, M. (2017). Panduan Mudah Belajar Arduino Menggunakan Simulasi Proteus. Andi: Yogyakarta.

[5] Prastika, L. R., Hamzah, H., Fatimah, \& Hendro. (2015). Detektor Ketebalan Kabut/Asap Berbasis Arduino Uno sebagai Antisipasi Terjadi Kecelakaan di Jalan Raya. Prosiding Simposium Nasional Inovasi Dan Pembelajaran Sains 2015 (SNIPS 2015), 2015(Snips), 97-100.

[6] Hamzah, H., Agriawan, M. N., \& Abubakar, M. Z. (2020). Analisis Tingkat Kebisingan Menggunakan Sound Level Meter berbasis Arduino Uno di Kabupaten Majene. J-HEST: Journal of Health, Education, Economics, Science, and Technology, 3(1), 25-32.

[7] Hamzah, H., Agriawan, M. N., \& Saldi, M. Z. (2021). Uji Kelayakan Konsumsi Air Sungai Mandar menggunakan Sensor $\mathrm{pH}$ berbasis Arduino Uno. SAINTIFIK. 7(2), 167-171.

[8] Andrianto, H. (2017). Arduino Belajar Cepat dan Pemrograman. Informatika: Bandung.
[9] Tsauqi, A. K., Hadijaya, M., Manuel. I., Hasan, V. M., Tsalsabilah, A., Chandra, F., Yuliana, T., Tarigan. P., Irzaman. 2016. SAKLAR OTOMATIS BERBASIS LIGHT DEPENDENT RESISTOR (LDR) PADA MIKROKONTROLER ARDUINO UNO. Prosiding Seminar Nasional Fisika (E-Journal). Vol V. http://snfunj.ac.id/kumpulan-prosiding/snf2016/

[10] Gunawan, E. \& Wahyono, E. (2017). Rancangan Instalasi Lampu Penerangan Jalan Umum Dengan Sistem Kontaktor Dan Timer. Jurnal Cahaya Bagaskara Vol. 1, No. 1.

[11] Novianti. K., Lubis. C., Tony. 2012. PERANCANGAN PROTOTIPE SISTEM PENERANGAN OTOMATIS RUANGAN BERJENDELA BERDASARKAN INTENSITAS CAHAYA. Seminar Nasional Teknologi Informasi.1-9.

[12] Sugiyono. (2018). Metode Penelitian Pendidikan. Alfabeta. 